\title{
Bacillus pumilus, a Novel Ginger Rhizome Rot Pathogen in China
}

Qin Peng, Yihui Yuan, and Meiying Gao, Key Laboratory of Agricultural and Environmental Microbiology, Wuhan Institute of Virology, Chinese Academy of Sciences, Wuhan, 430071, P.R. China

\begin{abstract}
Peng, Q., Yuan, Y., and Gao, M. 2013. Bacillus pumilus, a novel ginger rhizome rot pathogen in China. Plant Dis. 97:1308-1315.

Ginger rhizome rot is a major factor limiting the yield and marketability of ginger in Shandong Province, China. In order to identify the pathogen causing ginger rhizome rot, evaluate its pathogenicity, and explore its pathogenesis, diseased ginger rhizomes and surrounding soils were collected. A gram-positive, spore-forming, rod-shaped bacterium, designated GR8, was frequently isolated from the ginger rhizome samples. The bacterium was identified as Bacillus pumilus based on physio-biochemical and molecular biology characteristics. Patho-

tested rhizomes slices and the entire rhizome when wounded but no disease occurred when the rhizome was not wounded. Preliminary pathogenicity studies demonstrated that cell-free cultures of GR8 could not cause any disease symptoms, whereas the bacterial suspensions caused severe symptoms. The pathology studies revealed that infection of GR8 could cause starch grains to shrink from normal size, and destroy the parenchyma cells by invading and propagating in them. This is the first report of B. pumilus causing ginger rhizome rot.
\end{abstract} genicity studies with GR8 showed that it could cause disease of the
Edible ginger (Zingiber officinale Roscoe) is a popular spice crop, also used as a traditional Chinese medicine. It is widely cultivated in the provinces of Shandong, Sichuan, Anhui, and elsewhere in China. Diseases caused by pathogenic microbes such as bacteria $(14,21,42)$, fungi $(46)$, and pests $(23)$, are major factors restricting the efficient production of high-quality ginger. Bacterial wilt caused by Ralstonia solanacearum (Smith) Yabuuchi is one of the most devastating and prevalent diseases of ginger. Characteristic symptoms include wilting, foliar chlorosis, rhizomes with reduced quality because of discoloration or rotten tissue, and eventual death of ginger plants $(14,21)$. The bacterial wilt can result in a 20 to $70 \%$ loss of ginger yield in primary production regions (33). In recent years, serious outbreaks of ginger rhizome rot have occurred. Rhizome rot has gradually become one of the most devastating diseases of ginger in Shandong Province, which is one of the most important ginger production areas in China. The pathogenic bacteria causes ginger rhizome rot with foliar symptoms only during later growth stages, which differentiates it from the disease caused by $R$. solanacearum.

Bacillus pumilus is a member of the Bacillus subtilis group (9). Some Bacillus strains have been previously reported as plant pathogens, including B. circulans and B. pumilus. B. circulans has been reported to cause disease of date palm seedlings in the greenhouse $(25,26)$. B. megaterium pv. cerealis causes wheat white blotch (17). A Bacillus sp., identified as a possible B. pumilus strain, was associated with leaf and twig dieback of Asian pear trees in China (28). B. pumilus has been reported to cause leaf blight of mango trees in Egypt (11); however, up to now, $B$. pumilus has never been reported as a pathogen of ginger.

The mechanism of pathogenesis of $B$. pumilus in vivo has been never reported but a large number of enzymes with the potential to harm plant cells have been identified from this bacterium. The plant cell wall is primarily composed of cellulose, hemicellulose (mainly xylan), and lignin. Xylanase can harm plant cells and has been isolated from B. pumilus $(35,43)$. A newly isolated B. pumilus DKS1, which was used to degum ramie bast fibers, has shown high pectate lyase activity (3). A $\beta$-1,4-endoglucanase from an endo-

Corresponding author: M. Gao, E-mail: mygao@wh.iov.cn

Accepted for publication 28 March 2013.

http://dx.doi.org/10.1094/PDIS-12-12-1178-RE

(C) 2013 The American Phytopathological Society phytic B. pumilus strain was capable of hydrolyzing cellulose under in vitro conditions (29).

In this study, we characterized a B. pumilus strain, named GR8, isolated from rotted ginger rhizomes in Shandong Province, China. This is the first report of this bacterium causing ginger rhizome rot.

\section{Materials and Methods}

Plant materials used. Symptomless mature ginger rhizomes initiated from tissue culture (the 'Laiwu Big Ginger' type, the main cultivated variety in China, which is characterized by light yellow flesh, tangy flavor, and bulky rhizomes) were provided by the Institute of Ginger Research, Laiwu Academy of Agricultural Sciences.

Sample collection and isolation of a bacterial pathogen in ginger. Twelve symptomatic ginger rhizomes and six soil samples around the diseased rhizomes were collected from six different cultivated ginger fields in Shandong Province, China. The rhizome samples were immediately rinsed with tap water twice to remove any loosely adhering soil, soaked in $75 \%$ ethanol for $5 \mathrm{~min}$, and then washed in sterile distilled water once for $1 \mathrm{~min}$, soaked in $0.1 \%$ mercury bichloride for $10 \mathrm{~min}$, and washed in sterile distilled water six times. After air drying, tissue samples (about 1.0 by 1.0 by $1.0 \mathrm{~mm}$ ) were excised from the symptomatic rhizomes. The tissue samples were suspended in sterile distilled water and serial dilutions were spread on Luria-Bertani (LB) agar plates $(1 \%$ tryptone, $0.5 \%$ yeast extract, $1 \% \mathrm{NaCl}$, and $1.5 \%$ agar, $\mathrm{pH} 7.0$ to $7.5[\mathrm{wt} / \mathrm{vol}])$ according to the modified method of Nishijima et al (36). About 0.1 - to $0.2-\mathrm{g}$ soil samples were directly suspended in 1 $\mathrm{ml}$ of sterile distilled water and serial dilutions were spread on LB agar plates. The plates were incubated at $30^{\circ} \mathrm{C}$ for $24 \mathrm{~h}$. Single colonies were transferred to fresh plates and incubated under the same conditions. The process was repeated at least three times to obtain purified single colonies. The purified bacterial isolates were grown on LB agar medium at $30^{\circ} \mathrm{C}$ for 3 days and stored in glycerol suspensions $(20 \%, \mathrm{wt} / \mathrm{vol})$ at $-80^{\circ} \mathrm{C}$.

The modified semiselective media (SMSA) was used to isolate $R$. solanacearum, as described above. SMSA was composed of $0.1 \%$ casamino acid (wt/vol), $1 \%$ peptone (wt/vol), $1.5 \%$ agar (wt/vol), and $0.5 \%$ glycerol (vol/vol). After autoclaving, the medium was cooled to $55^{\circ} \mathrm{C}$ and the filter-sterilized following solutions were added (wt/vol): $0.005 \%$ 2,3,5-tripheny tetrazolium chloride, $0.0005 \%$ crystal violet, $0.01 \%$ polymyxin B sulfate, $0.0025 \%$ bacitracin, $0.0005 \%$ chloromycetin, and $0.00005 \%$ penicillin-G (38). $R$. solanacearum was determined by two-stage nested polymerase chain reaction (PCR) according to the modified method of Pradhanang et al. (38). The purified single colony from the LB 
plate or SMSA was suspended in $100 \mu \mathrm{l}$ of sterile distilled water, and the bacterial suspension was used as template for PCR after treatment at $-80^{\circ} \mathrm{C}$ for $30 \mathrm{~min}$, then boiled at $94^{\circ} \mathrm{C}$ for $10 \mathrm{~min}$. For the first stage, the PCR amplification was performed by using specific primers OLI-1 (5'-GGGGGTAGCTTGCTACCTGCC-3') and OLI-2 (5'-CGTCATCCACTCCAGGT-ATTAACCGAA-3') and the following procedure: denaturation at $94^{\circ} \mathrm{C}$ for $2 \mathrm{~min}$; followed by 35 cycles of denaturation at $94^{\circ} \mathrm{C}$ for $20 \mathrm{~s}$, annealing at $68^{\circ} \mathrm{C}$ for $20 \mathrm{~s}$, and extension at $72^{\circ} \mathrm{C}$ for $20 \mathrm{~s}$; and a final period of $10 \mathrm{~min}$ at $72^{\circ} \mathrm{C}$. The second-stage PCR was performed by using nested primer pairs JE2 (5'-GTGGGGGATAACTAGTCGAAAGAC-3')/Y2 (5'-CCCACTGCTGCCTCCCGTAGGAGT-3') and template from the first reaction product. In the second stage, 30 cycles of denaturation at $94^{\circ} \mathrm{C}$ for $20 \mathrm{~s}$, annealing at $55^{\circ} \mathrm{C}$ for $20 \mathrm{~s}$, and extension at $72^{\circ} \mathrm{C}$ for $20 \mathrm{~s}$ and a final period of $10 \mathrm{~min}$ at $72^{\circ} \mathrm{C}$ were used. The second PCR product was detected on $2 \%$ agarose gel with ethidium bromide $(0.5 \mathrm{mg} / \mathrm{ml})$. A specific PCR product of $172 \mathrm{bp}$ was predicted.

Based on colony and cell morphology, the 19 most frequently isolated strains were selected to evaluate pathogenicity on ginger rhizome slices to prove Koch's postulates. Each bacterial isolate was grown on an LB agar plate at $30^{\circ} \mathrm{C}$ for 12 to $24 \mathrm{~h}$; then, cells were resuspended in sterile distilled water. Using a multifunctional porous plate detector (Bio-tek synergy HT), the optical density at $600 \mathrm{~nm}\left(\mathrm{OD}_{600}\right)$ of the bacterial suspension was measured and adjusted to 0.5 , equivalent to $10^{9} \mathrm{CFU} / \mathrm{ml}$.

Inoculation tests were performed with ginger rhizome slices of pathogen-free rhizomes initiated from sterile tissue culture. The rhizomes were treated according to the method described by Nishijima et al. (36). Three 3-mm slices were placed onto sterile, moistened filter-paper in a petri dish ( $90 \mathrm{~mm}$ in diameter). An aliquot of $150 \mu \mathrm{l}$ of bacterial suspension containing approximately $10^{9}$ $\mathrm{CFU} / \mathrm{ml}\left(\mathrm{OD}_{600}\right.$ about 0.5$)$ was pipette inoculated into the center of each ginger slice. Ginger rhizome slices treated with $150 \mu$ of sterile distilled water were used as controls. The treated slices were incubated at $30^{\circ} \mathrm{C}$ for 3 days; then, symptomatic ginger slices were selected to reisolate the pathogen. The liquid on the surface of symptomatic ginger slices was collected and transferred to fresh LB plates. After incubation at $30^{\circ} \mathrm{C}$ for 12 to $24 \mathrm{~h}$, single colonies were picked to test pathogenicity. The pathogenicity tests were repeated three times.

PCR amplification of 16S rDNA from genomic DNA of tested strains. A DNA fragment of $16 \mathrm{~S}$ rDNA was amplified by PCR from 19 tested strain genomic DNA extracted using the method described by Gao et al. (12). The PCR amplification was performed by using primer pairs 27f/1492r (27f: $5^{\prime}$-AGAGTTTGATCCTGGCTCAG-3', 1492r: 5'-GGTTACCTTGTTACGACTT$\left.3^{\prime}\right)(8)$ and the following procedure: denaturation at $94^{\circ} \mathrm{C}$ for 5 min; followed by 35 cycles of denaturation at $94^{\circ} \mathrm{C}$ for $30 \mathrm{~s}$, annealing at $54^{\circ} \mathrm{C}$ for $90 \mathrm{~s}$, and extension at $72^{\circ} \mathrm{C}$ for $90 \mathrm{~s}$; and a final extension at $72^{\circ} \mathrm{C}$ for $7 \mathrm{~min}$. The PCR product was purified from $1.2 \%$ agarose with a Gel Extraction kit (OMEGA) and sequenced by Sangon Biotech (Shanghai) Co., Ltd. The 16S rDNA sequences of all test strains were analyzed with National Center for Biotechnology Information BLASTn 2.2.27 (1) and submitted to GenBank. A phylogenetic tree based on 16S rDNA sequences of GR8 was constructed using the neighbor-joining algorithm in MEGA software, version 5.0 (45). Based on the isolation results and similar sequence identity of the isolates, 1 of 19 strains, GR8, was selected for further study via physiological and biochemical tests and pathogenicity studies.

Physiological and biochemical tests. The isolate GR8 was characterized by assessing morphological, physiological, and biochemical characters (41). Colony morphology was described after incubation on $\mathrm{LB}$ plates at $30^{\circ} \mathrm{C}$ for 12 to $24 \mathrm{~h}$. Other bacteriological tests, including the Voges-Proskauer reaction, gelatin hydrolysis, growth at $\mathrm{pH} \mathrm{5}$, and growth at 8 and $45^{\circ} \mathrm{C}$, were carried out using standard methods (41). Carbon source utilization from substrates and other physiological and biochemical characteristics were determined with the API50CHB strips according to the manu- facturer's instructions (bioMerieux) (31). The bacterium was also identified by using the Biolog system (BIOLOG) (16). The size of GR8 cells was determined under a transmission electron microscope (HITACHI H-7000FA) at an acceleration voltage of $200 \mathrm{kV}$ with gram-stained cells from 12-h-old cultures (47).

Preparation of bacterial inocula. Strain GR8 was grown on an $\mathrm{LB}$ agar plate at $30^{\circ} \mathrm{C}$ for $12 \mathrm{~h}$. Cells were collected and suspended in $15 \mathrm{ml}$ of sterile distilled water at an $\mathrm{OD}_{600}$ of approximately 0.5 , which was equivalent to $10^{9} \mathrm{CFU} / \mathrm{ml}$. The bacterial suspension was used in pathogenicity tests as follows, and sterile distilled water was used as a control.

Pathogenicity tests in petri dishes. Pathogenicity tests with ginger rhizome slices of Laiwu Big Ginger initiated from tissue culture in petri dishes were conducted as described above. Briefly, a $150-\mu \mathrm{l}$ suspension of GR8 at approximately $10^{4}, 10^{5}, 10^{6}, 10^{7}$, $10^{8}$, or $10^{9} \mathrm{CFU} / \mathrm{ml}$ was inoculated into the center of each slice, and distilled water was used as a control. The inoculated slices in petri dishes were incubated at $30^{\circ} \mathrm{C}$ with a relative humidity of 40 to $70 \%$ for 2 days. Pathogenicity was evaluated according to the method described by Nishijima et al. (36). The disease severity rating, expressed as a percentage of rot over the total slice, was divided into five ratings, where $1=$ healthy tissue, $2=$ slight (up to $25 \%$ ) rot (slight discoloration), $3=$ moderate (up to 50\%) rot (discoloration and tissue breakdown), $4=$ severe rot (50 to $75 \%$ of slice affected), and $5=$ complete rot (up to the entire slice affected). The experiment was a completely randomized design and was repeated three times. Five slices were inoculated for each treatment. The disease severity ratings and disease incidences were recorded 2 days after GR8 inoculation. The means of disease severity rating values were analyzed using the Kruskal-Wallis test with the Statistical Program for Social Sciences (version 19; IBM SPSS Statistics). Dunn's multiple comparison test was used for Q comparisons of the values. Regression analysis on bacterial concentration versus disease severity rating was conducted by linear regression. The independent variable was the log value of bacterial concentration and dependent variable was disease severity ratings (27).

Pathogenicity tests in greenhouse. Whole ginger rhizomes of Laiwu Big Ginger initiated from tissue culture (about 7 to $8 \mathrm{~cm}$ in length with an existing bud) were surface disinfected as described above, then planted in pots containing sterilized sand. Two inoculation methods were used in separate experiments. In the first method, $5 \mathrm{ml}$ of bacterial suspension containing about $10^{9} \mathrm{CFU} / \mathrm{ml}$ was inoculated onto each nonwounded ginger rhizome. An equal volume of sterile distilled water was used as a control to treat ginger rhizomes. In the second method, six holes with diameters of about $0.5 \mathrm{~mm}$ each were made with sterilized toothpicks in each ginger rhizome, and then $5 \mathrm{ml}$ of bacterial suspension with about $10^{9} \mathrm{CFU} / \mathrm{ml}$ was inoculated into the holes. An equal volume of sterile distilled water was used as a control to treat ginger rhizomes. For each treatment, five ginger rhizomes were used and grown in a greenhouse at ambient temperature of 22 to $35^{\circ} \mathrm{C}$ and relative humidity of 40 to $70 \%$. After 40 to 45 days, disease incidences were recorded. Each inoculation experiment was repeated three times. After testing for homogeneity of variances with Levene's test, the disease incidence values were analyzed using the one-way analysis of variance (ANOVA) procedure of Statistical Program for Social Sciences (version 19; IBM SPSS Statistics). Fisher's protected least significant difference was used for mean comparisons (27).

Investigation of the bacterial pathogenesis. Ginger rhizome slices of symptomless Laiwu Big Ginger initiated from tissue culture and bacterial suspensions for petri dish tests were prepared as described above. GR8 was grown in LB broth at $30^{\circ} \mathrm{C}$ for 6,12 , 48 , and $72 \mathrm{~h}$. The cultures were filtered through $0.22-\mu \mathrm{m}$ filter membranes (Millipore). A $200-\mu$ l bacterial suspension (about $10^{9}$ $\mathrm{CFU} / \mathrm{ml}$ ) or filtered supernatant of GR8 cultures from different incubation times were inoculated into the center of each slice, and an equal volume of sterile distilled water was used as a control. The inoculated slices in petri dishes were incubated at $30^{\circ} \mathrm{C}$ for 4 
or 5 days, then visually evaluated for rot. For each treatment, three slices were used, and the experiments were repeated three times.

Observation of histopathological effects of GR8 on ginger rhizome. Ginger rhizome slices of Laiwu Big Ginger initiated from tissue culture used for pathogenicity tests were used to prepare the sections for observation of histopathological effects of GR8 on ginger rhizomes. The center of rhizome slices infected by bacterial suspension at $10^{9}$ and $10^{7} \mathrm{CFU} / \mathrm{ml}$ and treated with distilled water were cut into 2-mm-long cubes.

Paraffin method. The paraffin method was based on the method described by Azian et al., with some modifications (2). The cubes infected by bacterial suspension at $10^{9} \mathrm{CFU} / \mathrm{ml}$ and treated with distilled water were fixed in formol-aceto-alcohol for 3 days, dehydrated in a graded ethanol series $(50,70,85,95$, and 100\%) for $2 \mathrm{~h}$ each treatment. The tissues became transparent by treatment with increasing concentrations (50 and 100\%) of xylene mixed with ethanol, and then were infiltrated with increasing concentrations $(50,75$, and $100 \%)$ of paraffin wax .The specimens were cut to a thickness of 5 to $8 \mu \mathrm{m}$ with a rotary microtome (KD-2508 rotary microtome). Later, the ginger tissues were stained using Safranin and Fast Green and mounted with Canada Balsam. Then, the paraffin sections were observed under a light microscope (OlympusCX41).

Ultrathin section method. According to the method described by Carpentier et al. (4) and Nuzzo et al. (37), the cubes treated with bacterial suspensions of $10^{9}$ and $10^{7} \mathrm{CFU} / \mathrm{ml}$ and distilled water were fixed for $2 \mathrm{~h}$ with $2.5 \%$ glutaraldehyde in $0.1 \mathrm{M}$ sodium cacodylate buffer $(\mathrm{pH} 7.3)$ at room temperature. After several steps of sodium cacodylate buffer solution rinses, specimens were postfixed in $1 \%(\mathrm{wt} / \mathrm{vol})$ osmium tetroxide for $1 \mathrm{~h}$. Samples were rinsed in water and dehydrated in ethanol with graded concentrations (10 to $100 \%$ ). Subsequently, the absolute ethanol was substituted by propylene oxide, and increasing concentrations $(25,35,50,65,75$, and $100 \%$ ) of epoxy resin mixed with propylene oxide were infiltrated into specimens for 1 to $12 \mathrm{~h}$ per step. The resin was polymerized for $18 \mathrm{~h}$ at $60^{\circ} \mathrm{C}$. Ultrathin sections were stained by uranyl acetate and lead citrate solutions and examined under a transmission electron microscope (HITACHI H-7000FA).

\section{Results}

Isolation of bacterial pathogen and pathogenicity. To identify the pathogenic bacteria causing ginger rhizome rot, we isolated 200 strains from symptomatic ginger rhizomes and soil samples around the diseased ginger, and tested the pathogenicity of the 19 most frequently isolated strains on ginger slices. Among the tested strains, only GR8 caused rot symptoms in ginger rhizome slices (Fig. 1) and was reisolated from the symptomatic ginger slices. The other 18 tested strains shown in Table 1 did not cause rot on ginger rhizomes. In total, 17 strains (GR20 to GR36) were also

Table 1. Bacterial strains isolated from diseased ginger roots in China and their classification based on $16 \mathrm{~S}$ rDNA sequence analysis

\begin{tabular}{|c|c|c|c|}
\hline Isolate & $\begin{array}{l}\text { GenBank } \\
\text { accession }\end{array}$ & Source & $\begin{array}{l}\text { Classification based on } 16 \mathrm{~S} \\
\text { rDNA sequence analysis }\end{array}$ \\
\hline GR1 & КC009681 & Ginger & Enterobacter sp. \\
\hline GR2 & KC009682 & Ginger & Acinetobacter sp. \\
\hline GR3 & KC009683 & Soil & Enterobacter cloacae \\
\hline GR4 & KC009684 & Soil & Enterobacter sp. \\
\hline GR5 & KC009685 & Ginger & Enterobacter sp. \\
\hline GR6 & КС009686 & Ginger & Serratia marcescens \\
\hline GR7 & KC009687 & Ginger & Enterobacter sp. \\
\hline GR8 & JQ814631 & Ginger & Bacillus pumilus \\
\hline GR9 & КС009688 & Ginger & Enterobacter sp. \\
\hline GR10 & KC009689 & Ginger & Acinetobacter sp. \\
\hline GR11 & КC009697 & Ginger & Sphingobacterium sp. \\
\hline GR12 & КC009690 & Ginger & Acinetobacter sp. \\
\hline GR13 & KC009691 & Ginger & Pantoea agglomerans \\
\hline GR14 & KC009692 & Ginger & Pseudomonas fluorescens \\
\hline GR15 & KC009693 & Ginger & Pseudomonas sp. \\
\hline GR16 & KC009698 & Soil & Sphingobacterium sp. \\
\hline GR17 & КC009694 & Soil & Paracoccus sp. \\
\hline GR18 & KC009695 & Ginger & Bacillus sp. \\
\hline GR19 & КС009696 & Soil & Enterobacter ludwigii \\
\hline
\end{tabular}

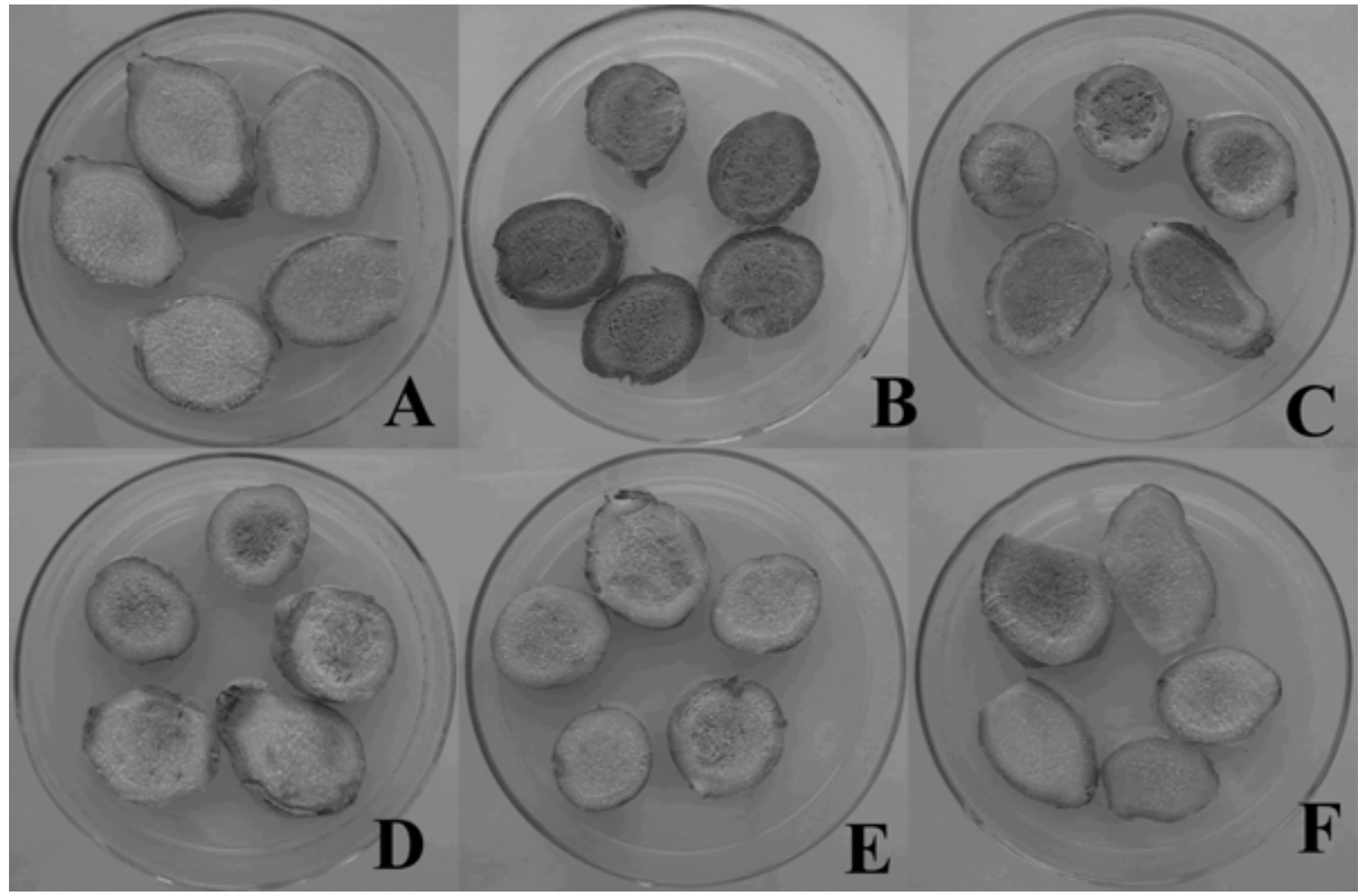

Fig. 1. Symptoms caused by Bacillus pumilus strain GR8 on rhizome slices. A, Healthy rhizome slices that were inoculated with sterile distilled water and incubated in petri dishes for 2 days at $30^{\circ} \mathrm{C}$. B and C, Severely rotten rhizome slices (symptoms: brown discoloration and water soaking) that were inoculated with a suspension of strain GR8 at $10^{9}$ and $10^{8} \mathrm{CFU} / \mathrm{ml}$, respectively. D-F, Mild rotten rhizome slices (symptoms: brown discoloration) that were inoculated with a suspension of strain GR8 at $10^{7}$, $10^{6}$, and $10^{5} \mathrm{CFU} / \mathrm{ml}$, respectively. 
isolated from 17 different samples in addition to the sample from which GR8 was isolated. These 17 strains were similar to GR8 in colony and cell morphology and pathogenicity to ginger slices. The samples from which GR8 and GR20 to GR36 were isolated were also investigated for $R$. solanacearum (Smith) Yabuuchi, which causes bacterial wilt. In all 18 samples, $R$. solanacearum was not detectable based on modified SMSA and nested PCR.

Mild symptoms of infection with GR8 included water-soaking, dark-yellow or tan-brown discoloration on the surface of the rhizome and rot on the surface, and no visible changes in the central cylinder (Fig. 2). Severe symptoms included brown discoloration of the surface and central cylinder, collapsed tissue, and a foul or putrid odor emitted from rhizomes that were rotten or spongy in texture. Based on these symptoms, this ginger disease was named ginger rhizome rot.

Identification of strain GR8. Bacterial strain GR8 formed subround, hyaline, faint-yellow colonies in the initial $12 \mathrm{~h}$ on LB plates; then, the colonies turned white with age. Gram staining and observation under a light microscope showed that GR8 was a spore-forming, gram-positive, rod-shaped bacterium. The dimensions of the bacterium were $707.32 \pm 37.56$ by $2501.37 \pm 118.34$ $\mathrm{nm}$. Based on the 16S rDNA sequencing, strain GR8 (GenBank accession JQ814631) had $99.4 \%$ sequence identity with $B$. pumilus strain KB66 (GenBank accession JF327485) and B. altitudinis (AJ831842). The strain also clustered with B. pumilus and $B$. altitudinis based on the phylogenetic analysis of the 16S rDNA sequence (Fig. 3). Physiological and biochemical characterization of strain GR8 indicated a greater similarity to B. pumilus than to $B$. altitudinis (Table 2). The API 50CHB strips exhibited $99.9 \%$ similarity with $B$. pumilus. The final result of the Biolog system showed $74.9 \%$ similarity to $B$. pumilus and relatively low similarity to other bacteria. Based on the physiological and biochemical characteristics, the biochemical profiles from the API 50CHB strips, the analysis of the Biolog system, and phylogenetic taxonomy, strain GR8 was identified as B. pumilus. In addition, the GR8-like strains GR20 to GR36, isolated from different samples, were also identified and considered to be $B$. pumilus according to their colonial morphology, physio-biochemical characteristics, and phylogenetic analysis (Fig. 3) based on 16S rDNA sequences (GenBank accessions KC771035 to KC771051).

Pathogenicity of strain GR8 on rhizome slices. The ginger slices were inoculated with suspensions of bacterium GR8 at approximately $10^{4}, 10^{5}, 10^{6}, 10^{7}, 10^{8}$, or $10^{9} \mathrm{CFU} / \mathrm{ml}$. After incubation for 2 days, the color of the ginger slices changed from pale yellow to brown, and all the slices were spongy in texture (Fig. 1B and C). Some water-soaking was observed when the rotten ginger slices were pressed slightly with a pipette, whereas the slices in the control showed no visible changes (Fig. 1A). Differences in disease severity ratings with different concentration suspensions of GR8 were difficult to prove with ANOVA (Table 3). No significant differences were also observed between the control and other concentration treatments, except for the $10^{9} \mathrm{CFU} / \mathrm{ml}$ concentration. Regression analysis showed that the disease severity rating was positively correlated with bacterial concentration $(y=0.4532 x+$ $0.2894, R^{2}=0.839$ ), and the disease severity rating increased 0.7426 when the bacterial concentration was raised 10 -fold. The result indicated that the GR8 strain was pathogenic $(P<0.0001)$ compared with the check (Table 3 ).

Pathogenicity in the greenhouse. Whole ginger rhizomes were planted in pots containing sterilized sand and incubated for 40 to 45 days. Ginger rhizomes with no surface wounds exhibited no obvious symptoms after treatment with a suspension of bacterium GR8 (Fig. 2A). However, when the symptomless ginger rhizomes were punctured with several holes and the bacterial suspensions were injected into the holes, severe symptoms of rot were observed

Table 2. Physiological and biochemical characteristics of strain GR8 isolated from ginger rhizome in China ${ }^{\mathrm{x}}$

\begin{tabular}{|c|c|c|c|}
\hline Characteristic & GR8 & $\begin{array}{l}\text { Bacillus pumilus } \\
{\text { MTCC } 1640^{\mathrm{T}}}\end{array}$ & $\begin{array}{l}\text { B. altitudinis } \\
\mathbf{4 1 K F 2 b ^ { T }}\end{array}$ \\
\hline Growth at $8^{\circ} \mathrm{C}$ & - & - & + \\
\hline Growth at $45^{\circ} \mathrm{C}$ & + & - & + \\
\hline Growth at pH 5 & - & - & + \\
\hline \multicolumn{4}{|l|}{ Hydrolysis of } \\
\hline Starch & - & - & + \\
\hline Casein & + & + & - \\
\hline Gelatin & + & - & + \\
\hline Voges-Proskauer test & + & + & - \\
\hline Utilization of citrate & + & + & \\
\hline \multicolumn{4}{|l|}{ Carbon source utilization } \\
\hline$N$-Acetylglucosamine ${ }^{y}$ & - & - & + \\
\hline D-Arabinose & - & - & + \\
\hline D-Cellobiose & + & - & + \\
\hline Dulcitol & - & - & + \\
\hline Glycerol & + & - & + \\
\hline Inulin & - & - & + \\
\hline D-Rhamnose & - & - & + \\
\hline D-Sorbitol & - & - & + \\
\hline L-Sorbose & - & - & + \\
\hline myo-Inositol ${ }^{\mathrm{z}}$ & - & - & + \\
\hline Pyruvate & - & - & + \\
\hline
\end{tabular}

${ }^{\mathrm{x}}$ Bacillus spp. according to Shivaji et al. $2006(40) ;+$ and - represent positive and negative reactions, respectively.

${ }^{y}$ Data were obtained by use of API50CHB test strips.

${ }^{z}$ Data were obtained by use of Biolog system.

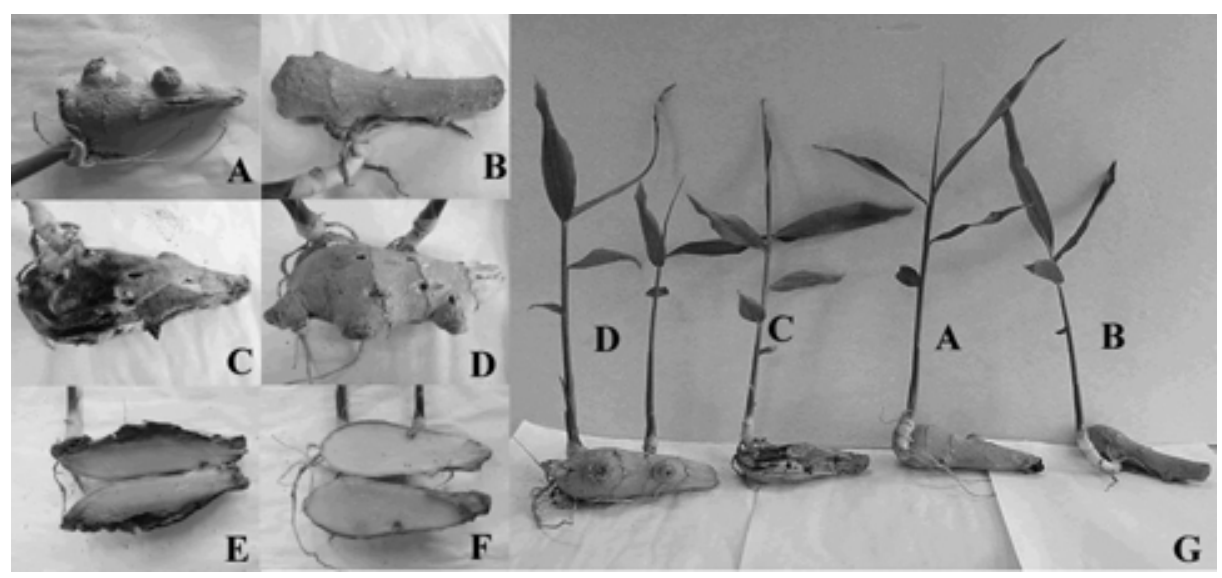

Fig. 2. Symptoms produced by Bacillus pumilus strain GR8 on whole rhizomes planted in the greenhouse. All the ginger rhizomes were grown in pots for 40 to 45 days at 22 to $35^{\circ} \mathrm{C}$ after treatment. A and B, Whole healthy rhizome without artificial wound holes on the surface, treated with strain GR8 at $10^{9} \mathrm{CFU} / \mathrm{ml}$ or sterile distilled water, respectively. C, Severe rot symptoms (brown discoloration, water soaking, and spongy tissue) on a ginger rhizome with wound holes on the surface, inoculated with strain GR8 at $10^{9} \mathrm{CFU} / \mathrm{ml}$. D, Symptomless rhizome with wound holes on the surface, treated with sterile distilled water. E, Bisected rhizomes treated with strain GR8 at $10^{9}$ $\mathrm{CFU} / \mathrm{ml}$. F, Bisected rhizomes treated with sterile distilled water. G, No foliar symptoms among ginger plantlets were evident. 


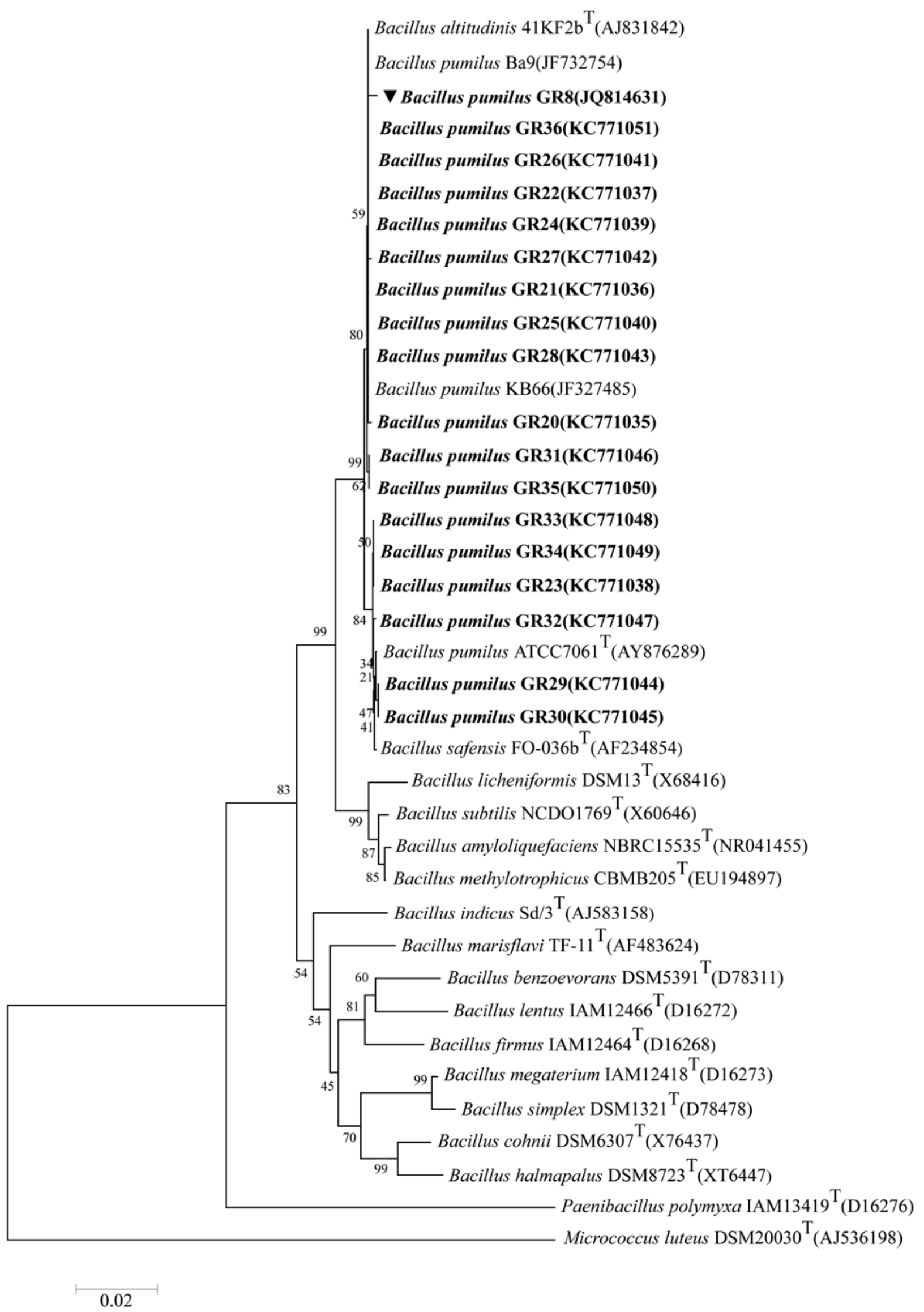

Fig. 3. Phylogenetic tree constructed with $16 \mathrm{~S}$ rDNA sequences using the neighbor-joining method and bootstrap analysis $(1,000$ replicates) in MEGA. Numbers in parentheses represent the GenBank accession numbers. Branch support with values of 50 or more are indicated at the branch nodes. The sequence from Micrococcus luteus DSM20030 ${ }^{\top}$ (AJ536198) was used as the outgroup. The scale bar represents 0.02 substitutions per nucleotide position. 
after incubation (Fig. 2C). The surface of the rotten ginger rhizome was collapsed, and the color changed from pale yellow to brown. When a rotten area of the ginger rhizome was cut out, we found that the central cylinder of the rhizome was collapsed and had severe, brown discoloration (Fig. 2E). No foliar symptoms were observed among the potted ginger plants (Fig. 2G). The planted ginger rhizomes used as controls showed no visible symptoms (Fig. 2B, D, and F). Disease incidence from the tests with wounded and nonwounded ginger rhizomes showed that significant differences $(P<0.0001)$ were evident (Table 4) when ginger rhizomes were inoculated with suspensions of GR8. No significant differences $(P>0.05)$ occurred in disease incidences among the other three treatments.

Pathogenesis of strain GR8. Ginger rhizome slices in petri dishes were treated with $200 \mu \mathrm{l}$ of GR 8 culture at $10^{9} \mathrm{CFU} / \mathrm{ml}$ or $200 \mu$ of cell-free supernatants of GR8 cultures from different incubation times, and the treated slices were incubated for 4 to 5 days. The cell-free supernatants from GR8 cultures that had grown for $6,12,48$, or $72 \mathrm{~h}$ did not produce any visible diseased symptoms when inoculated onto ginger rhizome slices (Fig. 4B-E), whereas the bacterial suspension caused visible symptoms (Fig. 4A).

Histopathological effect of GR8 to ginger rhizome. The histopathological effect of strain GR8 to ginger rhizome cell structure was investigated, and obvious differences were observed between healthy and diseased ginger rhizome tissues under the light microscope. The cross sections of healthy ginger rhizome tissue showed

Table 3. Effect of bacterial inoculum concentration on disease incidence and severity based on ginger slices inoculated with Bacillus pumilus strain GR8 in petri dish assays ${ }^{\mathrm{x}}$

\begin{tabular}{lccccc}
\hline & \multicolumn{2}{c}{ Disease incidence (\%) } & & \multicolumn{2}{c}{ Disease severity rating } \\
\cline { 2 - 3 } \cline { 5 - 6 } CFU/ml & Rep. & Mean \pm SD & & Rep. & Mean \pm SD \\
\hline $10^{9}$ & 15 & $100.0 \pm 0.0$ & & 15 & $5.0 \pm 0.0 \mathrm{a}$ \\
$10^{8}$ & 15 & $100.0 \pm 0.0$ & & 15 & $4.3 \pm 0.3 \mathrm{ab}$ \\
$10^{7}$ & 15 & $80.0 \pm 0.0$ & & 15 & $3.5 \pm 0.1 \mathrm{ab}$ \\
$10^{6}$ & 15 & $80.0 \pm 10.0$ & & 15 & $2.3 \pm 0.2 \mathrm{ab}$ \\
$10^{5}$ & 15 & $86.7 \pm 5.8$ & & 15 & $2.0 \pm 0.1 \mathrm{ab}$ \\
$10^{4}$ & 15 & $33.3 \pm 5.8$ & & 15 & $1.6 \pm 0.1 \mathrm{ab}$ \\
Control & 15 & $0.0 \pm 0.0$ & & 15 & $1.0 \pm 0.0 \mathrm{~b}$ \\
\hline
\end{tabular}

${ }^{x}$ Data represent disease severity rating based on a scale where $1=$ healthy tissue, 2 = slight (up to 25\%) rot (slight discoloration), $3=$ moderate (up to $50 \%$ ) rot (discoloration and tissue breakdown), $4=$ severe rot (50 to $75 \%$ of slice affected), and $5=$ complete rot (up to the entire slice affected). Rep. $=$ replicates of ginger slices; $\mathrm{SD}=$ standard deviation. Five ginger slices were used in each experiment and the experiment was repeated three times.

${ }^{y}$ Disease severity ratings were performed on three experiments. Data were analyzed using Kruskal-Wallis nonparametric test in SPSS19. Values followed by the same letters were not significantly different according to Dunn's multiple comparison test $(P<0.05)$. The experiment was repeated three times.

${ }^{\mathrm{z}}$ Bacterial concentration; control treatment was sterile distilled water.

Table 4. Pathogenic effect of Bacillus pumilus GR8 with wounded and nonwounded ginger rhizomes in greenhouse assays ${ }^{y}$

\begin{tabular}{lcc}
\hline Effect, ginger rhizomes & Rep. & Disease incidence $(\boldsymbol{\%})^{\mathbf{z}}$ \\
\hline B. pumilus GR8 & & \\
Wounded & 15 & $80.0 \pm 10.0 \mathrm{a}$ \\
$\quad$ Nonwounded & 15 & $6.7 \pm 5.8 \mathrm{~b}$ \\
Control & & \\
Wounded & 15 & $6.7 \pm 5.8 \mathrm{~b}$ \\
Nonwounded & 15 & $0.0 \pm 0.0 \mathrm{~b}$ \\
\hline
\end{tabular}

${ }^{\mathrm{y}}$ Rep. $=$ replicates of ginger rhizomes. There were five roots per treatment in each experiment. Control treatment was sterile distilled water. The experiment was repeated three times.

${ }^{z}$ Data were analyzed by a one-way analysis of variance procedure with SPSS19; mean \pm standard deviation are shown. Values followed by the same letters were not significantly different according to Fisher's protected least significant difference test $(P<0.05)$. well-defined parenchyma cells and an abundance of normal-size starch grains (Fig. 5A and B), However, in symptomatic rhizomes, the parenchyma cells were disrupted and the starch grains were reduced in size (Fig. 5C and D). The effect of strain GR8 infection on the parenchyma cells was also observed under transmission electron microscopy. The results showed that the pathogen GR8 could invade the parenchyma cells, and the numbers of the invading bacterium increased as the concentration of bacterial cells increased (Fig. 5F and G). The pathogen was not found in the parenchyma cells of the cross section from healthy ginger (Fig. 5E).

\section{Discussion}

In this study, a bacterial pathogen, B. pumilus GR8, causing ginger rhizome rot was isolated and identified. The strain was isolated frequently from all the samples of symptomatic ginger rhizomes and soils collected from different cultivated ginger fields in Shandong Province of China. This was the first report of $B$. pumilus being pathogenic to ginger rhizomes. Ginger rhizome rot in Shandong Province of China was previously only thought to be caused by $R$. solanacearum (Smith) Yabuuchi (13). However, $R$. solanacearum was not isolated or detected with PCR from the diseased ginger rhizomes and soil samples, whereas B. pumilus, including strain GR8, was isolated from all the samples and was highly pathogenic to ginger rhizomes. B. pumilus strains could also cause rot symptoms in ginger rhizome slices. Rot symptoms were usually produced by $B$. pumilus GR8 on the surface of whole ginger rhizomes when a wound was present; therefore, wounding was necessary for GR8 to be pathogenic. This result corresponded with the report of Galal et al. (11). Based on the fact that B. pumilus GR8 only infected wounded ginger, we considered that $B$. pumilus GR8 was a secondary pathogen of ginger rhizomes (6). In contrast to symptoms caused by Enterobacter cloacae (36) and $R$. solanacearum (15) at early growth stages, strain GR8 only resulted in foliar symptoms at later growth stages. Thus, with strain GR8, it is much more difficult to identify diseased ginger plants and separate them from healthy ginger plants in commercial production fields.

B. pumilus GR8 can cause extremely severe symptoms of rot in ginger rhizomes in a short time with a concentration of $10^{9}$ $\mathrm{CFU} / \mathrm{ml}$ (Table 3; Fig. 2). For this reason, an outbreak of disease caused by the bacterium may result in severe losses in ginger production in a short period. Therefore, studies of this strain are important and may be helpful for control of ginger disease.

In previous reports, $B$. pumilus was widely used as a biocontrol agent against fungal $(7,10,19,20,34,44)$ and bacterial $(5,18,24,32)$ pathogens. $B$. pumilus was usually applied to prevent plant disease

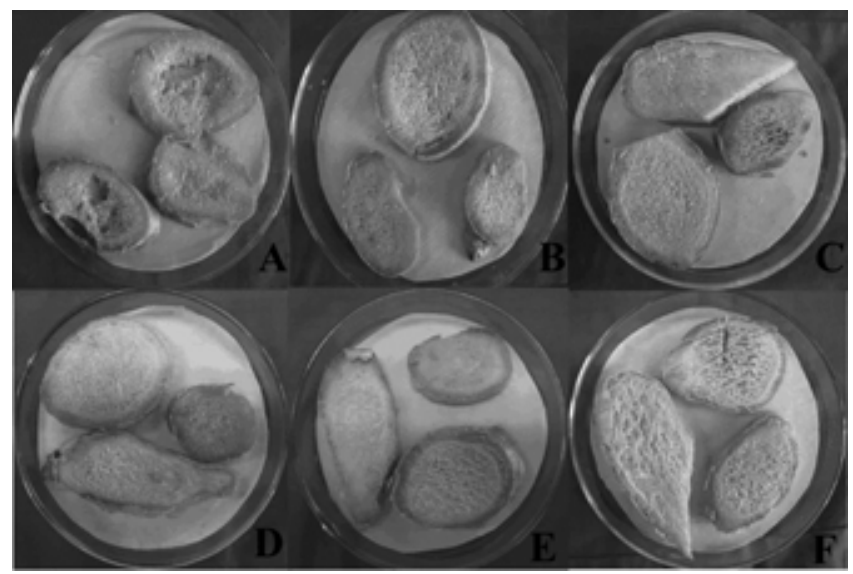

Fig. 4. Symptoms of rhizome slices after treatment with a bacterial suspension or with cell-free supernatants of Bacillus pumilus strain GR8 cultures. All the ginger rhizome slices were incubated in petri dishes for 4 to 5 days at $30^{\circ} \mathrm{C}$ after treatment. A, Severe rot symptoms (water soaking and spongy tissue) of rhizome slices inoculated with bacteria grown for $12 \mathrm{~h}\left(10^{9} \mathrm{CFU} / \mathrm{ml}\right)$. B-E, Rhizome slices inoculated with cell-free supernatants from GR8 cultures that were grown 6, 12, 48, or $72 \mathrm{~h}$, respectively. F, Rhizome slices treated with sterile distilled water. 


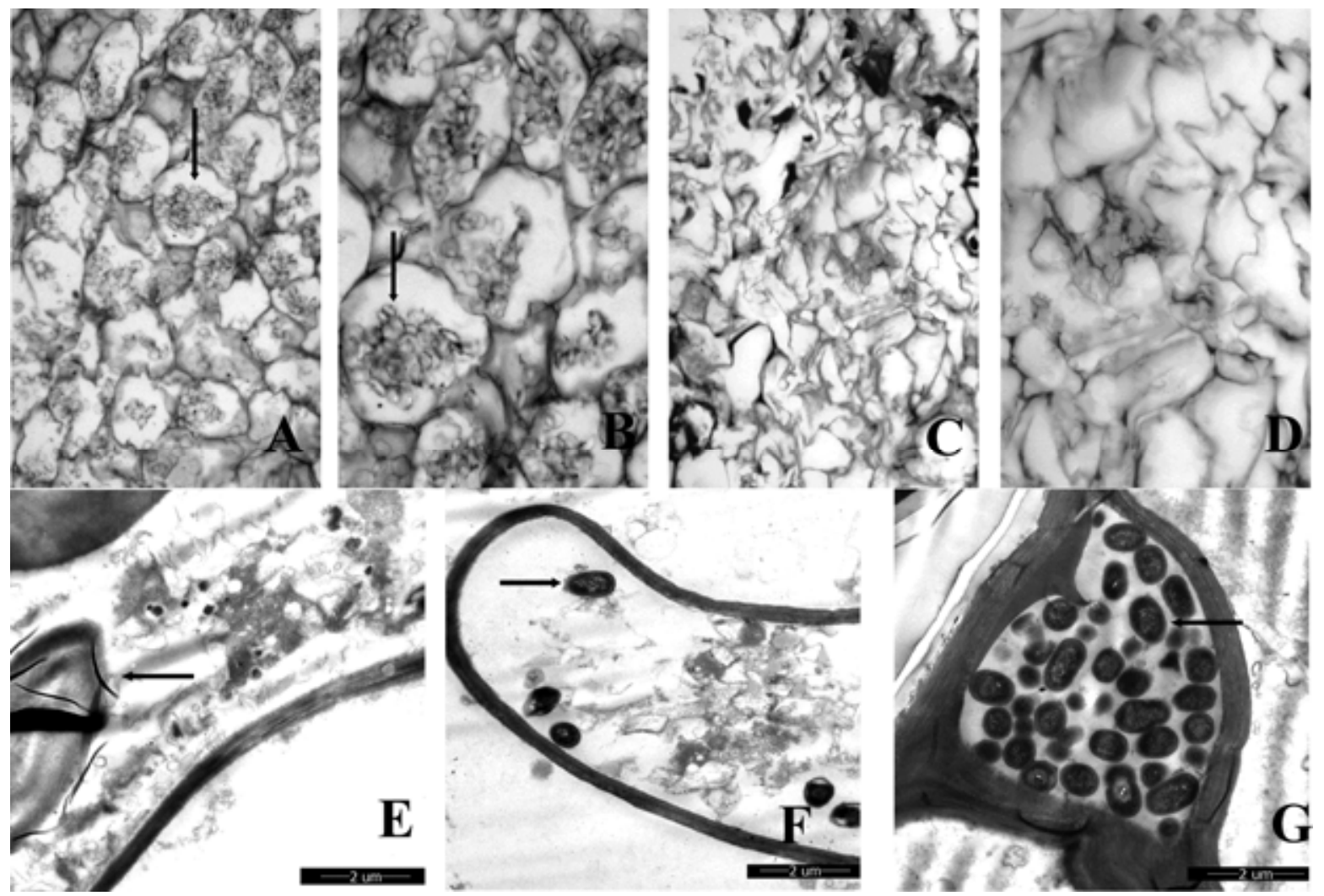

Fig. 5. Pathological effect of Bacillus pumilus strain GR8 to ginger rhizome. $\mathbf{A}$ and $\mathbf{B}$, Optical micrographs of a cross section of healthy ginger rhizome tissue taken at $\mathbf{A}$, $\times 20$ and $\mathbf{B}, \times 40$. C and $\mathbf{D}$, Optical micrographs of a cross section of diseased ginger rhizome tissue taken at $\mathbf{C}, \times 20$ and $\mathbf{D}, \times 40$. E-G, Transmission electron micrograph of a cross section of ginger rhizome tissue (scale bars $=2 \mu \mathrm{m}$ ). Tissue treated with $\mathrm{E}$, sterile distilled water or bacterial suspensions of $\mathrm{F}, 10^{7} \mathrm{CFU} / \mathrm{ml}$ or $\mathrm{G}, 10^{9} \mathrm{CFU} / \mathrm{ml}$. Arrows in $A$ and $B$ indicate the starch grain and arrows in $G$ and $F$ indicate the pathogenic bacteria.

and was used as a plan- growth-promoting rhizobacteria (34) but, in our study, B. pumilus caused severe rot in ginger rhizomes. Because of insect injury (23), climate, artificial cultivation, and so on, ginger rhizomes can easily become wounded on the rhizome surface. Moreover, B. pumilus has been reported as a human pathogen, and showed potential as a bloodstream pathogen during infancy (22). It has occasionally been isolated from cases of foodassociated illness (30). Therefore, the security and applicability of B. pumilus as a biocontrol agent remains debatable.

Pathogenic bacteria that have been reported to cause plant disease by producing exopolysaccharide or exoproteins (pectinolytic enzymes and cellulolytic enzymes), such as $R$. solanacearum, could cause bacterial wilt in several plants (39). Preliminary bacterial pathogenesis studies indicated that cell-free cultures of GR8 could not cause any ginger rhizome rot. The result suggested that strain GR8 did not produce any pathogenic toxin to cause ginger rhizome rot. We deduced from the optical micrographs that the pathogen GR8 could destroy the parenchyma cells and cause the starch grains to shrink. Transmission electron micrographs also showed that strain GR8 could invade the parenchyma cells; therefore, we hypothesize that the pathogenesis of GR8 might be due to growth of the strain on a substance in ginger rhizomes. Alternatively, some substance within living cells of GR8 could cause rot of ginger rhizomes.

\section{Acknowledgments}

This study was supported by the National Natural Science Foundation of China (No.31170123, 31201560), the National project (2009ZX08009-056B), and the projects of the Chinese Academy of Sciences (KSCX2-EW-G-16).

\section{Literature Cited}

1. Altschul, S. F., Madden, T. L., Schaffer, A. A., Zhang, J. H., Zhang, Z., Miller, W., and Lipman, D. J. 1997. Gapped BLAST and PSI-BLAST: a new generation of protein database search programs. Nucleic Acids Res. 25:3389-3402

2. Azian, M. N., Kamal, A. A. M., and Azlina, M. N. 2004. Changes of cell structure in ginger during processing. J. Food Eng. 62:359-364.

3. Basu, S., Saha, M. N., Chattopadhyay, D., and Chakrabarti, K. 2009. Largescale degumming of ramie fibre using a newly isolated Bacillus pumilus DKS1 with high pectate lyase activity. J. Ind. Microbiol. Biot. 36:239-245.

4. Carpentier, A., Abreu, S., Trichet, M., and Satiat-Jeunemaitre, B. 2012. Microwaves and tea: new tools to process plant tissue for transmission electron microscopy. J. Microsc. Oxford 247:94-105.

5. Chithrashree, Udayashankar, A. C., Nayaka, S. C., Reddy, M. S., and Srinivas, C. 2011. Plant growth-promoting rhizobacteria mediate induced systemic resistance in rice against bacterial leaf blight caused by Xanthomonas oryzae pv. oryzae. Biol. Control 59:114-122.

6. Daniel, C. R., Gupta, A. K., Daniel, M. P., and Sullivan, S. 1998. Candida infection of the nail: role of Candida as a primary or secondary pathogen. Int. J. Dermatol. 37:904-907.

7. Essghaier, B., Fardeau, M. L., Cayol, J. L., Hajlaoui, M. R., Boudabous, A., Jijakli, H., and Sadfi-Zouaoui, N. 2009. Biological control of grey mould in strawberry fruits by halophilic bacteria. J. Appl. Microbiol. 106:833-846.

8. Frank, J. A., Reich, C. I., Sharma, S., Weisbaum, J. S., Wilson, B. A., and Olsen, G. J. 2008. Critical evaluation of two primers commonly used for amplification of bacterial 16S rRNA genes. Appl. Environ. Microbiol. $74: 2461-2470$.

9. Fritze, D. 2004. Taxonomy of the genus Bacillus and related genera: the aerobic endospore-forming bacteria. Phytopathology 94:1245-1248.

10. Fu, G., Huang, S. L., Ye, Y. F., Wu, Y. G., Cen, Z. L., and Lin, S. H. 2010. Characterization of a bacterial biocontrol strain B106 and its efficacy in controlling banana leaf spot and post-harvest anthracnose diseases. Biol. Control 55:1-10.

11. Galal, A. A., El-Bana, A. A., and Janse, J. 2006. Bacillus pumilus, a new pathogen on mango plants. Egypt. J. Phytopathol. 34:17-29.

12. Gao, M. Y., Li, R. S., Dai, S. Y., Wu, Y., and Yi, D. 2008. Diversity of $B a-$ cillus thuringiensis strains from soil in China and their pesticidal activities. Biol. Control 44:380-388.

13. Guangmin, Z., Guoqiang, F., Hancheng, Z., Jifa, Z., Jiaoyi, W., Aiyun, D., Qingsheng, R., Zhenwei, L., and Xiujuan, S. 2001. Study on the pathogen of the ginger wilt disease in Shandong. J. Shandong Agric. Univ. (Nat. Sci.) $32: 418-422$.

14. Hayward, A. C. 1964. Characteristics of Pseudomonas solanacearum. J. Appl. Bacteriol. 27:265-277.

15. He, L. Y., Sequeira, L., and Kelman, A. 1983. Characteristics of strains of Pseudomonas solanacearum from China. Plant Dis. 67:1357-1361.

16. Hill, J. E., Baiano, J. C. F., and Barnes, A. C. 2009. Isolation of a novel 
strain of Bacillus pumilus from penaeid shrimp that is inhibitory against marine pathogens. J. Fish Dis. 32:1007-1016.

17. Hosford, R. M. 1982. White blotch incited in wheat by Bacillus megaterium pv. cerealis. Phytopathology 72:1453-1459.

18. Hu, H. Q., Li, X. S., and He, H. 2010. Characterization of an antimicrobial material from a newly isolated Bacillus amyloliquefaciens from mangrove for biocontrol of Capsicum bacterial wilt. Biol. Control 54:359-365.

19. Huang, X. Q., Zhang, N., Yong, X. Y., Yang, X. M., and Shen, Q. R. 2012. Biocontrol of Rhizoctonia solani damping-off disease in cucumber with $\mathrm{Ba}$ cillus pumilus SQR-N43. Microbiol. Res .167:135-143.

20. Huang, Y., Wild, B. L., and Morris, S. C. 1992. Postharvest biologicalcontrol of Penicillium digitatum decay on citrus-fruit by Bacillus pumilus. Ann. Appl. Biol. 120:367-372.

21. Ishii, M., and Aragaki, M. 1963. Ginger wilt caused by Pseudomonas solanacearum E. F. Smith. Plant Dis. Rep. 47:710-713.

22. Kimouli, M., Vrioni, G., Papadopoulou, M., Koumaki, V., Petropoulou, D., Gounaris, A., Friedrich, A. W., and Tsakris, A. 2012. Two cases of severe sepsis caused by Bacillus pumilus in neonatal infants. J. Med. Microbiol. 61:596-599.

23. Koya, K. M. A. 1990. Role of rhizome maggot Mimegralla coeruleifrons macquart in rhizome rot of ginger. Entomology 15:75-77.

24. Lanna, R., Romeiro, R. D., and Alves, E. 2010. Bacterial spot and early blight biocontrol by epiphytic bacteria in tomato plants. Pesqui. Agropecu. Bras. 45:1381-1387.

25. Leary, J. V., and Chun, W. W. C. 1989. Pathogenicity of Bacillus circulans to seedlings of date palm (Phoenix dactylifera). Plant Dis. 73:353-354.

26. Leary, J. V., Nelson, N., Tisserat, B., and Allingham, E. A. 1986. Isolation of pathogenic Bacillus circulans from callus cultures and healthy offshoots of date palm (Phoenix dactylifera L). Appl. Environ. Microbiol. 52:11731176.

27. Levesque, R. 2007. SPSS Programming and Data Management: A Guide for SPSS and SAS Users, Fourth Edition. SPSS Inc., Chicago.

28. Li, B., Qiu, W., Tan, Q. M., Su, T., Fang, Y., and Xie, G. L. 2009. Association of a Bacillus species with leaf and twig dieback of Asian pear (Pyrus pyrifolia) in China. J. Plant Pathol. 91:705-708.

29. Lima, A. O. S., Quecine, M. C., Fungaro, M. H. P., Andreote, F. D., Maccheroni, W., Araujo, W. L., Silva-Filho, M. C., Pizzirani-Kleiner, A. A., and Azevedo, J. L. 2005. Molecular characterization of a beta-1,4-endoglucanase from an endophytic Bacillus pumilus strain. Appl. Microbiol. Biot. 68:57-65.

30. Logan, N. A. 2012. Bacillus and relatives in foodborne illness. J. Appl. Microbiol. 112:417-429.

31. Logan, N. A., and Berkeley, R. C. 1984. Identification of Bacillus strains using the Api system. J. Gen. Microbiol. 130:1871-1882.

32. Luna, C. L., Mariano, R. L. R., and Souto-Maior, A. M. 2002. Production of a biocontrol agent for crucifers black rot disease. Braz. J. Chem. Eng. 19:133-140.

33. Ming, L., Min, Z., Junchen, J., Fuqiang, Y., Yu, Z., Yong, T., and Yajun, Y.
2005. Advances in research bacterial wilt of ginger in China. Chin. Agric Sci. Bull. 121:337-340.

34. Myresiotis, C. K., Karaoglanidis, G. S., Vryzas, Z., and PapadopoulouMourkidou, E. 2012. Evaluation of plant-growth-promoting rhizobacteria, acibenzolar-S-methyl and hymexazol for integrated control of Fusarium crown and root rot on tomato. Pest Manage. Sci. 68:404-411.

35. Nagar, S., Mittal, A., Kumar, D., and Gupta, V. K. 2012. Production of alkali tolerant cellulase free xylanase in high levels by Bacillus pumilus SV205. Int. J. Biol. Macromol. 50:414-420.

36. Nishijima, K. A., Alvarez, A. M., Hepperly, P. R., Shintaku, M. H., Keith, L. M., Sato, D. M., Bushe, B. C., Armstrong, J. W., and Zee, F. T. 2004 Association of Enterobacter cloacae with rhizome rot of edible ginger in Hawaii. Plant Dis. 88:1318-1327.

37. Nuzzo, V., Aptel, F., Savoldelli, M., Plamann, K., Peyrot, D., Deloison, F., Donate, D., and Legeais, J. M. 2009. Histologic and ultrastructural characterization of corneal femtosecond laser trephination. Cornea 28:908-913.

38. Pradhanang, P. M., Elphinstone, J. G., and Fox, R. T. V. 2000. Sensitive detection of Ralstonia solanacearum in soil: a comparison of different detection techniques. Plant Pathol. 49:414-422.

39. Schell, M. A. 2000. Control of virulence and pathogenicity genes of Ralstonia solanacearum by an elaborate sensory network. Annu. Rev. Phytopathol. 38:263-292.

40. Shivaji, S., Chaturvedi, P., Suresh, K., Reddy, G. S. N., Dutt, C. B. S., Wainwright, M., Narlikar, J. V., and Bhargava, P. M. 2006. Bacillus aerius sp. nov., Bacillus aerophilus sp. nov., Bacillus stratosphericus sp. nov. and Bacillus altitudinis sp. nov., isolated from cryogenic tubes used for collecting air samples from high altitudes. Int. J. Syst. Evol. Microbiol. 56:1465-1473.

41. Staley, J. T., Bryant, M. P., Pfennig, N., and Holt, J. G. 1989. Bergey's Manual of Systematic Bacteriology. Lippincott Williams and Wilkins, Baltimore, MD.

42. Stirling, A. M. 2002. Erwinia chrysanthemi, the cause of soft rot in ginger (Zingiber officinale) in Australia. Australas. Plant Pathol. 31:419-420.

43. Subramaniyan, S. 2012. Isolation, purification and characterisation of low molecular weight xylanase from Bacillus pumilus SSP-34. Appl. Biochem. Biotech 166:1831-1842.

44. Swadling, I. R., and Jeffries, P. 1996. Isolation of microbial antagonists for biocontrol of grey mold disease of strawberries. Biocontrol Sci. Technol. 6:125-136.

45. Tamura, K., Peterson, D., Peterson, N., Stecher, G., Nei, M., and Kumar, S 2011. MEGA5: molecular evolutionary genetics analysis using maximum likelihood, evolutionary distance, and maximum parsimony methods. Mol Biol. Evol. 28:2731-2739.

46. Wang, P. H., Chung, C. Y., Lin, Y. S., and Yeh, Y. 2003. Use of polymerase chain reaction to detect the soft rot pathogen, Pythium myriotylum, in infected ginger rhizomes. Lett. Appl. Microbiol. 36:116-120.

47. Williams, C. M., Richter, C. S., Mackenzie, J. M., and Shih, J. C. H. 1990 Isolation, identification, and characterization of a feather-degrading bacterium. Appl. Environ. Microbiol. 56:1509-1515. 